CrossMark \& click for updates

Cite this: DOI: $10.1039 / \mathrm{c} 6 \mathrm{mb} 00227 \mathrm{~g}$

Received 28th March 2016,

Accepted 16th June 2016

DOI: $10.1039 / \mathrm{c} 6 \mathrm{mb} 00227 \mathrm{~g}$

www.rsc.org/molecularbiosystems

\title{
Application of post-genomic techniques in dog cancer research
}

\author{
F. Ceciliani, * P. Roccabianca, C. Giudice and C. Lecchi
}

\begin{abstract}
Omics techniques have been widely applied to veterinary science, although mostly on farm animal productions and infectious diseases. In canine oncology, on the contrary, the use of omics methodologies is still far behind. This review presents the most recent achievement in the application of postgenomic techniques, such as transcriptomics, proteomics, and metabolomics, to canine cancer research. The protocols to recover material suitable for omics analyses from formalin-fixed, paraffinembedded tissues are presented, and omics applications for biomarker discovery and their potential for cancer diagnostics in veterinary medicine are highlighted.
\end{abstract}

\section{Introduction}

Cancer is one of the leading causes of death in dogs. Approximately $50 \%$ of dogs 10 years or older develop cancer and in $25 \%$ it is considered the cause of death (http://www.acfoundation. org/). ${ }^{1}$ As the average lifespan continues to rise in dogs, cancer in pet animals is expected to become one of the most relevant health problems in veterinary medicine. Certain spontaneous dog cancers are particularly attractive as a model for the

Department of Veterinary Medicine, Università di Milano, Via Celoria 02, 20133 Milano, Italy. E-mail: fabrizio.ceciliani@unimi.it; Fax: +39 2 50318095; Tel: +39250318100

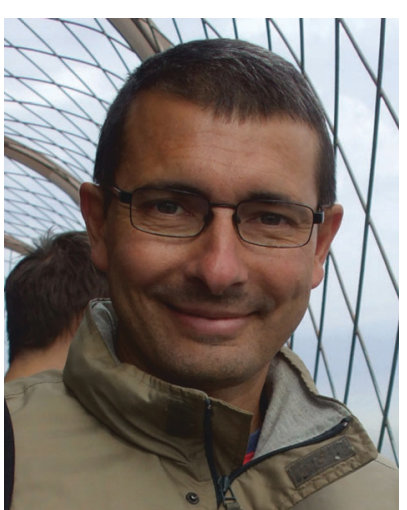

F. Ceciliani
Fabrizio Ceciliani, DVM, PhD, is an Associated Professor of Veterinary Pathology at the University of Milano. He graduated in Veterinary Medicine at the University of Milano. In 1994 gained a PhD in Biochemistry and in 1995 gained a post doc position in Molecular Biology at the University of Milano. Current interests include the immune response in white blood cells. The involvement of adipose tissue in innate immune response is also under investigation. A second, important, research topic includes post-translational modification of proteins involved in acute and chronic inflammations. These studies are routinely carried out in cattle and cats, where it was investigated in FIV, FIP and FeLV. corresponding human disease. Noteworthy, dogs are genetically close to humans; they share the same environmental challenges, receive a high level of healthcare, ${ }^{2}$ and many naturally occurring cancers are the same as for humans., Moreover, combination chemotherapy and radiation therapy are now commonly administered to companion animals and responsiveness to conventional antitumour therapies shares many similarities among humans and dogs. ${ }^{5,6}$ Additionally, in specific breeds, such as boxers and golden retrievers, the incidence of tumours such as lymphoma is even higher (one every four and one every eight, respectively), ${ }^{7-9}$ providing important information about a hereditary and genetic basis for cancer.

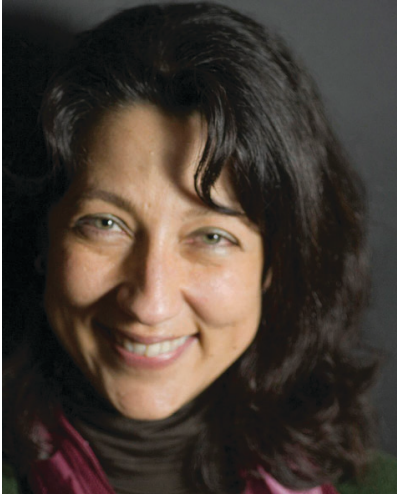

P. Roccabianca
In 1994 obtained the doctorate degree in comparative pathology with a thesis on pathological and molecular characterization of canine lymphomas. In 1995 achieves the J. Fullbright scholarship for a postdoctoral position at UC Davis (CA) working on feline mucosal immunology and LGL leukemias. In 1998-2000 tenure track investigator at the School of Veterinary Medicine of Padova In 2000 obtains the ECVP board certification. Currently, is associate professor at the University of Milano. Research focus is on mucosal immunology, lymphoproliferative disorders and sarcomas in small animals. Diagnostic focus on immunopathology and dermatopathology of small animals. In 2007 receives the CL Davis Foundation Journal Award for the best international veterinary pathology paper. 
Cancer is a complex disease. Effective therapy and positive prognosis rely on early diagnosis and adequate classification of cancer type, providing information necessary for targeted therapies. ${ }^{10}$ In human medicine, the application of highthroughput omics has been proven useful to investigate cancerogenesis. In canine oncology, on the contrary, the application of omics techniques is still far behind. We present here the most recent achievement in the application of omics techniques, including proteomics, transcriptomics, and metabolomics, in canine cancer research. Although very informative about cancer pathogenesis, genomics studies on chromosome modifications in dog cancer fall outside the scope of this paper and have been recently reviewed elsewhere. ${ }^{2,11}$

\section{Postgenomic techniques applied to canine oncology}

Proteomic and postgenomic applications in veterinary medicine are increasing exponentially although most of them have been carried out on farm animals. ${ }^{12}$ Studies in companion animals mostly focus on pathogenesis and diagnostics of infectious diseases and cancer. ${ }^{11,13}$

To date, few databases are made available for the dog species. The dog genome was published in $2005,{ }^{14}$ and an improved version was recently published. ${ }^{15}$ Table 1 presents an updated list of canine protein and DNA databases.

Table 2 presents the proteomic reference maps for canine fluids, which provide the prerequisite for omics investigations.

The proteomic maps of canine biological fluids have been also recently reviewed. ${ }^{27}$

Next generation sequencing (NGS) (Fig. 1) and gel-free high throughput proteomics (Fig. 2) stand at the cutting edge of the techniques currently used for data acquisition in molecular

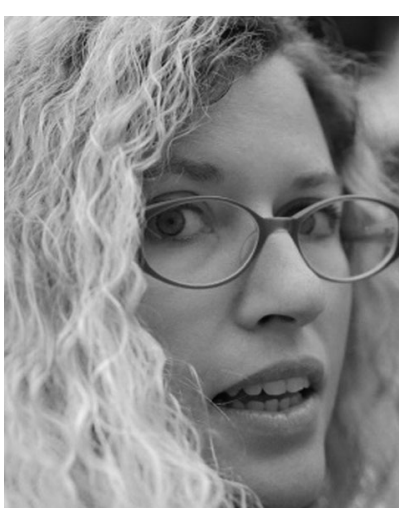

C. Giudice
Chiara Giudice is researcher at School of Veterinary Medicine (University of Milan). She obtained her PhD in 2001, with a thesis on ocular pathology, after a period at the COPLOW (held by Prof. Dubielzig, Wisconsin Veterinary Medical School). She ECVP diplomated in 2009. Her research interest is focused on ocular pathology and comparative oncology. She is currently staff member of the departmental diagnostic laboratory and she runs a service for Ocular Pathology diagnostic. Dr Giudice is an active member in professional societies (ESVP; ECVP; SOVI; AIPVET). She is a member of the Faculty PhD Board and Departmental Commission for Research.
Table 1 Protein and DNA databases dedicated to dogs

\begin{tabular}{ll}
\hline Data bank & Web address \\
\hline $\begin{array}{l}\text { Phylogenetic } \\
\text { mitochondrial DNA } \\
\text { tree }^{16}\end{array}$ & http://clf.mtdna.tree.cm.umk.pl/ \\
$\begin{array}{l}\text { Dog Genome SNP } \\
\begin{array}{l}\text { Database (DoGSD) } \\
\text { Entrez database }\end{array}\end{array}$ & http://dogsd.big.ac.cn/ \\
& $\begin{array}{l}\text { http://www.ncbi.nlm.nih.gov/projects/map } \\
\text { view/static/dogsearch.html } \\
\text { http://www.crb.ucp.pt/salivatec/canisome/ }\end{array}$ \\
$\begin{array}{l}\text { NoniSome coding RNA } \\
\text { Non }\end{array}$ & $\begin{array}{l}\text { http://genome.ucsc.edu/cgi-bin/hgGate } \\
\text { Dog assembly and } \\
\text { gene annotation }\end{array}$ \\
& $\begin{array}{l}\text { way?hgsid=480309867_Zct4maej2YfZU4tPaEYm } \\
\text { VEO6WMxp }\end{array}$
\end{tabular}

pathogenesis and biomarker research in cancer and are probably poised to replace microarrays (Fig. 3) and two-dimensional gel electrophoresis (2DGE) (Fig. 2) in the years to come.

So far, microarrays and 2DGE are still the workhorses among omics applied to canine oncology, and they should be regarded as complementary to NGS and gel-free proteomics. ${ }^{28,29}$ A thorough review of methods currently available for omics studies, including their potentials and limitations in veterinary medicine, has been published. ${ }^{30}$ Not surprisingly, omics techniques were applied mainly to the study of the most common cancer types in dogs, namely mammary gland carcinoma and blood malignancies, although other types of cancer, such as bladder adenocarcinoma, mastocytoma, and osteosarcoma, have been investigated, taking advantage of high throughput omics techniques.

\section{Mammary gland tumours}

Mammary gland tumours are considered the most common malignancies in female dogs of geographical areas where spaying is retarded or not routinely performed..$^{31}$ Prevalence is

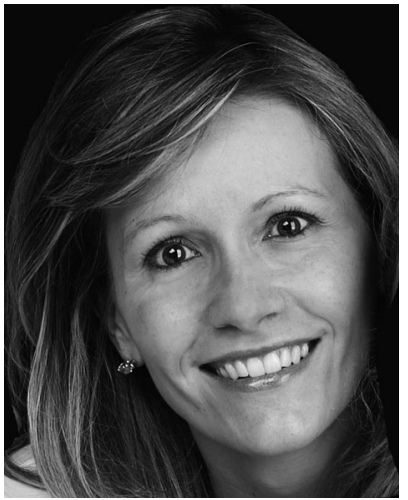

C. Lecchi
Cristina Lecchi is a molecular biologist with focus on immunity and identification of biomarkers useful in veterinary medicine. She graduated in 2003 in Veterinary Biotechnology at the Università degli Studi di Milano and defended her PhD thesis in January 2009. From 2008 to 2002 she worked as a post doc at Università degli Studi di Milano working on localisation and immune function of acute phase proteins. From 2012 to 2015 she worked as a junior researcher (class A) in Veterinary Pathology. From 2016 she is a Junior Reseracher (class B), teaching Molecular Pathology and Immunopathology in Veterinary Biotechnology. From 2013 to 2015 she was a member of the evaluation board of the Università degli Studi di Milano in charge of the evaluation of PhD programs. 
Table 2 Dog proteomic maps

\begin{tabular}{ll}
\hline Tissue & Technique \\
\hline Urinary proteome $^{20}$ & LC-MS/MS \\
Blood serum $^{21}$ & 2D/MS \\
Bronchoalveolar lavage fluid $^{22}$ & 2-DIGE/MS \\
Cerebrospinal fluidd $^{23}$ & 2D/MALDI-TOF \\
Mammary cell line $^{24}$ & 2D/MALDI-TOF/TOF-MS \\
Tears $^{25}$ & 1D/MALDI-TOF-MS/MS \\
Tears $^{26}$ & 2D/MALDI-TOF
\end{tabular}

LC-MS/MS, liquid chromatography-mass spectrometry; 2D/MS, 2D gel electrophoresis/mass spectrometry; 2-DIGE/MS, 2-D fluorescence difference gel electrophoresis/mass spectrometry; 2D/MALDI-TOF, 2D gel electrophoresis/matrix-assisted laser desorption ionisation-time of flight.

up to $0.2 \%$, and death usually occurs following metastatic disease. The incidence of canine mammary gland neoplasms is estimated at $50 \%$ of all neoplasms in this species. ${ }^{32}$ Spontaneously occurring mammary gland cancer provides a good model for human breast cancer. ${ }^{33-36}$ The knowledge of the molecular aspects of mammary gland tumours in dog has been very recently reviewed. ${ }^{37,38}$ A recent investigation analysed in molecular depth the homologies and the differences between mammary gland cancers of dogs and humans by combining whole-genome sequencing, whole-exome sequencing, RNA sequencing, and microarray analysis of simple and complex carcinomas. The authors found that canine simple carcinomas presented genomic aberrations, and were molecularly similar to human breast carcinomas. In addition, canine complex carcinomas were characterised by modification of genes involved in chromatin remodelling, suggesting that the development of this group of cancers may be related to epigenomic alterations. ${ }^{39}$

\section{Omics in the characterisation of mammary gland-derived tumour cell lines}

Tumour-derived cell lines are widely used as the primary experimental model system to study tumour pathogenesis and therapy. The transcriptome of primary tumour cell cultures has been demonstrated as corresponding to transcriptome of parental tumour tissues. ${ }^{40}$ Five mammary adenocarcinoma cell lines, namely PL-20, CMT-W1, CMT-W2, P114, and CMT-U27, were selected for gene expression studies, ${ }^{41}$ sorting the cells in (a) high proliferation potential, (b) high antiapoptotic potential, and (c) high metastatic potential. DNA microarray was used to identify associations between cell potential and gene expression. Consistent with phenotypical features, high proliferation rate potential was associated with the expression of genes encoding for growth hormone and ghrelin, high antiapoptotic potential was associated to $B C R$-related genes and TMD1, and metastatic potential was associated to elevated expression of $P G O P, S E M A 3 B$, and $S T M 1$. The reliability of mammary cell lines as a model to study mammary gland adenocarcinoma allowed investigation of the impact of progesterone on the development of mammary cancer, by comparing differences in gene expression between cells derived from progestininduced hyperplasia, spontaneous mammary tumours, and healthy mammary tissues. ${ }^{42}$ The expression pattern of progestin-induced canine hyperplasia was characterised by upregulation of 50 genes including, among the others, PCNA and RAS family members. Moreover, 75 genes were found to be downregulated. The gene expression profile of the canine mammary tumour cell line was different: 69 genes were found to be upregulated. This group included genes involved in cell adhesion and motility, such as CCLAL1 and Fibronectin 1, and proliferation, such as $\beta$-catenin 1. An additional 110 genes were also found to be downregulated.

Working with in vitro cell systems provides the unique opportunity to identify the role of each individual component in the onset, development, and progression of malignant phenotypes, as well as the interaction with other cell types, such as white blood cells and fibroblasts. Co-culturing canine mammary cell lines with macrophages allowed demonstration

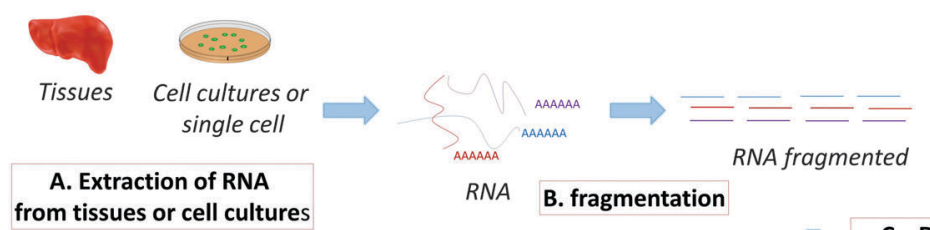
from tissues or cell cultures
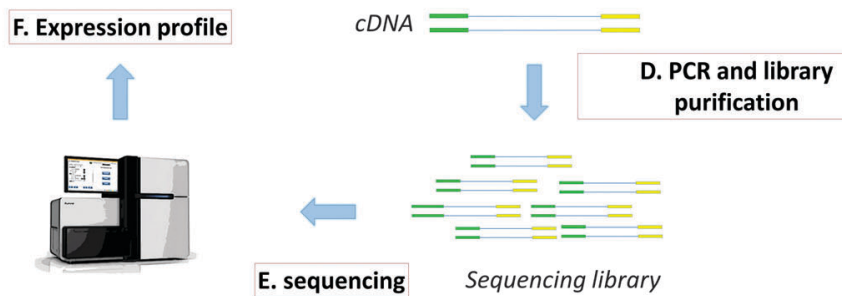

Fig. 1 RNA-seq workflow. The workflow begins with poly-A-mRNA purification using poly-T beads. The RNA is cleaved into fragments of $100-200$ bp by enzymatic reaction or by chemical hydrolysis. The fragmented RNA is converted into a double-stranded cDNA library. RNA fragments are hybridised and ligated to an adapter mixture using the RNA ligase. The adaptors' linked RNA is converted to single strand cDNA using reverse transcriptase and purified. The cDNA library is finally enriched with PCR and then purified. During the PCR step it is also possible to introduce specific short DNA sequences acting as barcodes to identify different samples. The final product consists of dsDNA molecules of 200-300 bp containing the copies of the RNAs present in the original sample surrounded by adapters and creates the final cDNA library. 


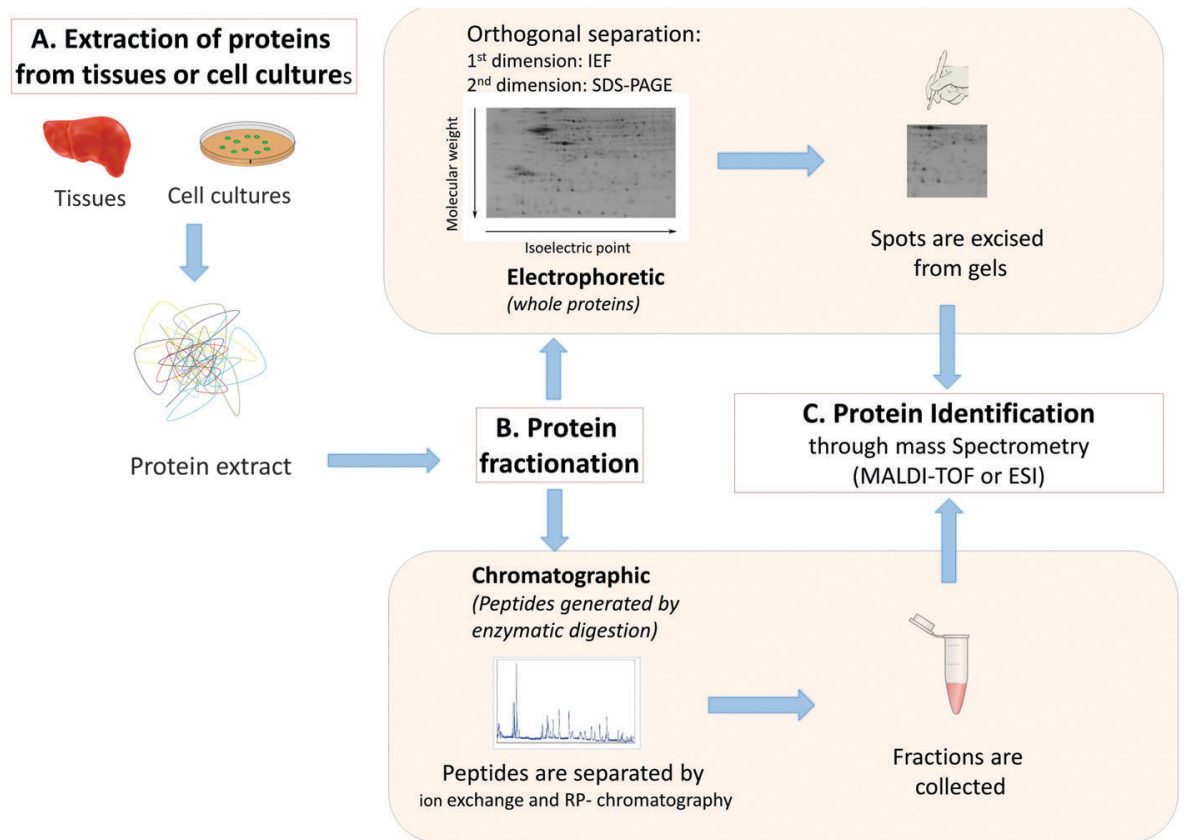

Fig. 2 Proteomic workflow. The proteomic workflow starts with the extraction of proteins from tissues or cell cultures. The protein fractionation may be either electrophoretic (upper panel), or chromatography (lower panel). The electrophoretic fractionation system former is applied to intact proteins. Conventional 2DE involves separation of protein by means of isoelectric focusing in the first dimension, which is thereafter followed by sodium dodecyl sulphate electrophoresis in the second dimension. Both dimensions are carried out in a polyacrylamide gel matrix. The proteins migrate on $2 \mathrm{D}$ gels as spots according to an isoelectric point and apparent molecular weight. The resulting spots can be excised directly from the gel for characterisation by mass spectrometry (MS). The chromatographic fractionation system includes a trypsin digestion of the protein extract to generate peptides that can be further fractionated by high performance liquid chromatography (HPLC). The chromatography eluate flows into an ESI-MS (LC-MS). The MS records the mass of analytes and also isolates and fragments peptide ions (MS/MS, or tandem MS) to generate information about structure.

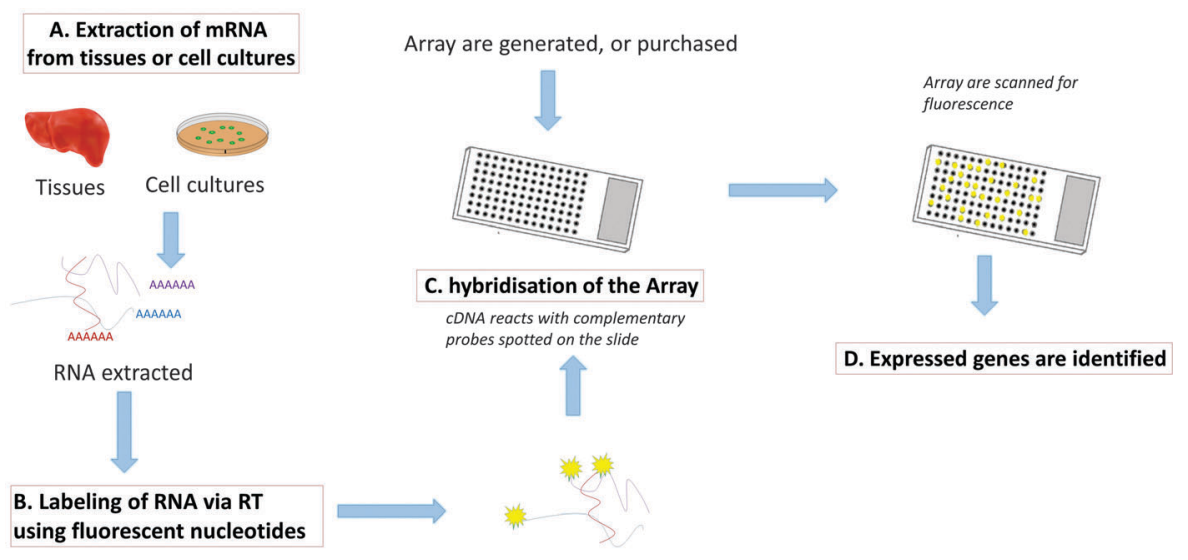

Labeled CDNA

Fig. 3 Microarray workflow. The workflow starts with RNA purification and retrotranscription to double-stranded cDNA. After purification, cDNA are fluorescently labelled with distinct fluorescent dyes - such as, Cy-3 (green) and Cy-5 (red)-and detected by hybridisation onto immobilised DNA probes on the microarray. Each sample sequence (target) hybridises to the complementary strand on the array (probe) allowing confirmation of the presence of a target gene. Multiple DNA probes are spotted on a thin support-such as, silicium, glass, or polymers-with each one being specific for a DNA or RNA target sequence.

of the impact of the Wnt pathway in cancer transformation. ${ }^{43,44}$ After co-culturing with macrophages, cancer cells express some macrophage-specific antigens, such as CD14, CD64, CD163, and CSFR, as well as macrophages attracting proteins. Remarkably, macrophages co-cultured with cancer cells produce ligands involved in Wnt pathway (Wnt5b, Wnt7a, and Wnt7b).
Differences in microRNA expression have indicated that a switch from canonical Wnt to noncanonical Wnt pathway also occurs, providing evidence that the interplay between intratumoural macrophages and mammary cancer cells may also rely on epigenetic regulation. Epigenetic regulation of cancer cell has also been recently investigated using mammary cancer 
stem-like cells. ${ }^{45}$ MicroRNA profiling was carried out and found that 33 microRNA were dysregulated, the most relevant being miR-451 (upregulated) and miR-135b (downregulated). Both these microRNAs were already found to be dysregulated in human counterpart, ${ }^{46,47}$ although in mammary cancer cells the miR-135b was found to be mostly upregulated.

Carcinoma-associated fibroblasts provide the main cancer stromal structure. ${ }^{48}$ Gene expression studies of cancer cell lines co-cultured with carcinoma-associated fibroblasts have demonstrated that 100 genes were upregulated in cancer cells as compared to individual cell lines. ${ }^{49}$ This group of genes codes for proteins involved in cell adhesion, such as chondroadherin, CLEC7A, protocadherin-19, desmoplakin, and VCAM-1, and angiogenesis, such as EMT. A group of 106 genes was also found to be downregulated; this list includes an antiangiogenic protein (ADAMTS15), and a cell adhesion molecule (CADM4). Proteomic profiling of in vitro adenocarcinoma cells has been also carried out. A mammary adenocarcinoma cellular line was established and proteome was characterised by 2-DGE and MALDI-TOF, ${ }^{24}$ providing the background for a study aimed to identify potential autoantigens by applying serological proteome analysis (SERPA).$^{50-52}$ Proteins derived from tumour cancer lines were separated by 2-DGE and blotted onto PVDF membranes, and incubated with serum obtained from dogs with mammary gland tumours. Four autoantigens were identified, namely Mn-SOD, trioso phosphate isomerase, alpha-enolase, and phosphoglycerate mutase 1 , and results were validated with immunohistochemistry and Western blotting. These findings reported for the first time an autoantibody response in canine mammary adenocarcinoma, confirming what has been previously found for human breast cancer.

\section{Cancer progression and development of metastatic clones}

One of the most striking features of mammary adenocarcinoma is the development of metastatic clones, which eventually causes patient death. A transcriptomic study compared lymph node metastases with the corresponding non neoplastic mammary tissue. ${ }^{53}$ A total of 730 genes were found to be upregulated-including genes associated with cell cycle progression (cyclins/CDK, DNA replication genes), and metalloproteinases. Conversely, 580 genes were found to be downregulated in metastatic lymph nodes, including angiogenesis and adhesion molecules, together with genes coding for seven proteinase inhibitors. Regulators of mammary gland development-such as hormone receptors, steroid metabolism, growth factor receptors, genes associated with carbohydrate/lipid metabolism, and genes involved in negative regulators of cell cycle progression-were also downregulated, as well as transmembrane rectors, namely TGFBR2, PDGF1, VEGFR1, and FGFR1, suggesting that the metastatic cell phenotype is less differentiated as compared to the normal one.

The transcriptomic profile from canine adenocarcinoma lines was compared with that of lines isolated from their respective lung metastases. ${ }^{54}$ Fifteen genes, belonging to signal transduction, developmental processing, and apoptosis pathways, were found to be upregulated in metastatic cell lines, highlighting the role of growth hormone secretagogue receptor (GHSR) as a candidate for pulmonary metastatic signature.

A second parallel study was carried out on 13 mammary carcinomas with lymph node metastases and 14 carcinomas without lymph node metastases. ${ }^{55}$ Results demonstrated that metastatic carcinomas have 1011 differentially expressed genes as compared with non metastatic carcinomas. Cell cycle checkpoint genes and DNA damage repair genes were upregulated in metastatic carcinoma, whereas growth factor receptor pathways and cell differentiation genes were downregulated, somehow in contrast with other findings previously reported. ${ }^{54}$ Adhesion-related genes were also differentially regulated, and angiogenesis-related genes were downregulated. Out of the 1011 differentially expressed genes, 265 genes were also reported as dysregulated in human breast cancer. Moreover, a significant overlap with human breast cancer prognostic signature was also found, providing further evidence that spontaneous cancer in bitches can be regarded as a good model for the human counterpart.

Changes in gene expression in mammary cancer cell lines after co-culturing with myeloid-derived suppressor cells (MDSC) were recently investigated. ${ }^{56}$ Microarray analysis gene expression revealed that 107 genes were significantly upregulated in cell lines after MDSC treatment, most of them being involved in inflammation, interleukin signalling pathway, and cytoskeletal regulation. The study then focused on the IL-28/IL-28R pathway by knocking down IL-28R, and demonstrated that treatment with IL-28 promotes angiogenesis, epithelial-mesenchymal transition, and enhances mammary tumour invasion and migration.

Beside transcriptomics, also proteomics approaches were applied to obtain further insights into the molecular features of metastatic progression. Two groups of canine mammary carcinomas, one group with metastasis to the regional lymph nodes and one group without metastases, were compared by means of 2D-DIGE and differentially expressed spots were identified with MALDI-TOF. ${ }^{57}$ Eleven proteins were found to be upregulated in metastatic cancers. This group included proteins involved in cell proliferation and division, such as EF1 delta and Ran/TC4binding proteins. Downregulated proteins in the metastatic cancer group included vinculin and tropomyosin 1 (cell adhesion) and c myosin light chain 2 and calretinin (cell motility). Protein inhibitors were both up- and downregulated in the metastatic cancer group (serpin 5 was upregulated, whereas serpin B10 was downregulated). In addition, stress-related/ scavenger proteins were differentially regulated: TXNDC5 was upregulated, and peroxiredoxin 6 was downregulated. The expression of only five of the differentially expressed proteins was validated by RT-PCR, suggesting that posttranscriptional regulation of these molecules occurred. A comparison between normal, benign, nonmetastatic and metastatic mammary gland tumours was investigated by applying 2D-DIGE and MALDITOF analysis. ${ }^{58}$ Although no linear changes in the expression of individual proteins were detected during the progression from adenoma to metastatic cancer, the results defined three patterns: an adenoma pattern was characterised by changes in the expression of 13 proteins, a carcinoma pattern with 9 differentially expressed proteins, and a metastatic carcinoma 
pattern, where 20 proteins were found to be differentially expressed as compared to each of the two previous stages. These results suggested that progression toward malignancy was not linear, but followed a stepwise increase or decrease of protein expression levels. Six proteins displayed a significant change in their expression level, and four could be identified, namely EF1 delta, vinculin, ferritin light polypeptide, and hemopexin, highlighting their possible use as possible markers for metastatic pattern.

Breast sarcomas are much more uncommon, and microarray technology was applied to compare gene expression patterns of mammary carcinoma with those of mammary gland fibrosarcomas and osteosarcoma; ${ }^{59}$ focus was on homeobox transcription factors, which were known to upregulate during mammary gland tumours. As compared to other type of mammary tumours, osteosarcomas exhibited an upregulation of BMPs and gene associate with retinoic acid signalling. Results were also validated by means of immunohistochemistry and after stimulating an osteosarcoma cell line with BMP-2, providing the background to demonstrate the importance of BMPs protein expression in the development of osteosarcoma mammary tumours. ${ }^{60}$

\section{Biomarkers for early diagnosis and prognosis}

Not surprisingly, several studies have been directed to identify cancer biomarkers in serum of dogs affected from mammary adenocarcinoma. Given that the presence of circulating tumour cells in peripheral blood provides relevant prognostic clues for human breast cancer, a pilot study was carried out to identify the presence of mRNA in circulating tumour cells. Two canine carcinoma cell lines were diluted with blood from healthy animals, and their transcriptomes were compared with those of white blood cells collected from healthy animals (da Costa et al., 2012), ${ }^{61}$ demonstrating that two genes, namely ATP8B1 and $C R Y A B$, were the most sensitive genes; although AGR2, $I R X 3, F 3$, and $S L C 1 A 1$ were detected, the three last genes have never been identified before.

\section{Blood malignancies}

Lymphomas are most common haematopoietic neoplasms in dogs, being responsible for approximately $24 \%$ of all canine cancer diagnoses. ${ }^{4}$ Canine lymphomas share several epidemiological, biological, and clinical features with the human counterpart, in particular the non-Hodgkin lymphomas, ${ }^{62-64}$ and its use as a comparative model for human non-Hodgkin lymphoma has been recently reviewed. ${ }^{65,66} \mathrm{~A}$ comparison between human and dog lymph nodes forming diffuse large B-cell lymphoma ${ }^{67}$ demonstrated that the gene expression profile was similar. A germinal centre phenotype could be differentiated from a postgerminal centre phenotype in canine B-cell lymphoma, although it was not evident, at a molecular level, how close this differentiation in dog corresponded to the human germinal centre B-cell and activated B-cell. Dog lymphoma also provided a model to study the relationship between heritable factors and the development of the disease (Fig. 4). ${ }^{9}$

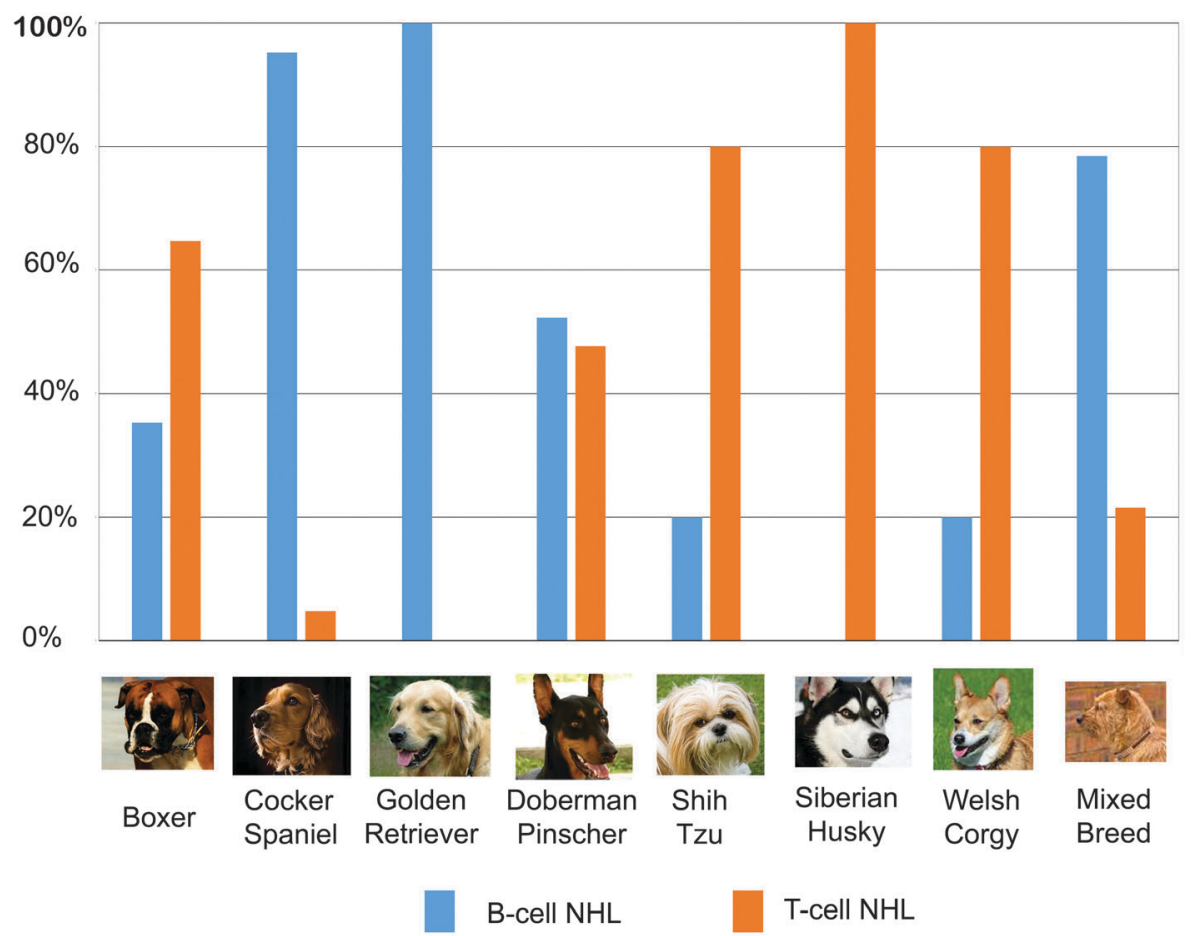

The prevalence of B-cell and T-cell Non Hodgkin lymphoma between dog breeds

Fig. 4 B-cell and T-cell prevalence of non-Hodgkin lymphoma among breeds. Breeds exhibit statistical differences between the reference population (mixed bred dogs). Data are elaborated from Modiano et al. ${ }^{9}$ 
Transcriptional profiling can be carried out from surgical biopsies and from fine needle aspirations. ${ }^{68}$ Fine needle aspirated samples have been used to compare-with different techniques (RNA-seq and microarray) - the changes in the B-cell lymphoma transcriptome. ${ }^{69}$ The experiment focused on the use of phosphatidylinositol 3-kinase (PI3-K) inhibitor. Both RNA-seq and microarrays identified similar sets of expressed genes in lymphoma, although RNA-seq was more sensitive. A custom-designed microarray including genes involved in the NF- $\kappa$ B pathways and other genes, which were previously found to be dysregulated during lymphoma, was designed ${ }^{70}$ to investigate gene expression in lymph nodes from dogs with diffuse large B-cell lymphoma. Results were compared with equivalent human samples. The most important finding was that $54 \mathrm{NF}-\kappa \mathrm{B}$ target genes were dysregulated in human lymphoma, whereas $17 \mathrm{NF}-\kappa \mathrm{B}$ target genes were differentially regulated in the correspondent canine disease. Other canine genes indirectly related to NF- $\mathrm{BB}$ were differently expressed; specifically, genes coding for CD40LG, LCK, LTBR, and TNFSF11 were downregulated, while genes coding for EIF2AK2 and MYD88 were upregulated.

A large canine lymphoma exome sequencing study has been carried out on three dog breeds that spontaneously develop lymphoma, namely boxers (T-cell), cocker spaniels (B-cell), and golden retrievers (B- and T-cell). ${ }^{71}$ Recurrent mutations were found in TRAF-MAP3K14, FBXW7, and POT1, with evident similarities between B-cell lymphomas from golden retrievers and cocker spaniels. T-cell lymphomas from boxers carried mutations in the tumour suppressor PTEN-mTOR signalling pathway. Mutations of the T-cell lymphomas from boxers and golden retrievers did not overlap. Although almost $50 \%$ of the mutated genes were found to be involved also in human lymphoma, several mutations, such as those in NLRP family, were new, and others, namely PSMA1 and KPNA2, were never reported in human lymphoma, but have been observed in other types of human cancer. Molecular profiling of samples from naturally occurring lymphoma was carried out after RNA isolation and microarray. ${ }^{72}$ Gene expression profiling allowed for subdivision of the most common subtypes of canine lymphoma ${ }^{73}$ into three molecular subgroups, namely highgrade T-cell lymphoma, low-grade T-cell lymphomas, and B-cell lymphomas. Gene signature identified 389 genes that were differentially expressed between T-high grade and T-low group, and 624 genes differentiated between B-cell and T-cell lymphomas. Gene expression results supported the design of a simple diagnostic platform relying on some genes, including $C D 28$ and $A B C A 5$, differentiating T-cell from B-cell lymphomas, and $C C D C 3$ and $S M O O C 2$ ratio differentiating T-low grade from T-high grade lymphoma. Proteomics analysis was carried out by 2D electrophoresis followed by MALDI-TOF on lymph nodes from lymphoma affected animals before chemotherapy was given. ${ }^{74}$ The authors found that at least four proteins were differentially expressed between the proteomes of lymph nodes of dogs with lymphoma as compared to those of healthy dogs. Four proteins, namely prolidase, triosephosphate isomerase, and glutathione $S$-transferase, were found to be downregulated, whereas one protein, MCP, was upregulated. The importance of
MCP was recently confirmed also in transitional cell carcinoma of urinary bladder cancer in dogs. ${ }^{75}$ Remarkably, this paper was the first to identify MCP as cancer biomarker. Other studies on different human malignancies ${ }^{76-80}$ validated MCP as a cancer biomarker, further supporting the use of dogs as useful models for human cancer.

Studies on the serum proteome changes of canine lymphoma have been carried out by combining ion exchange chromatography and surface-enhanced laser desorption ionisation (SELDI) mass spectrometry. A classification and regression tree (CART) bioinformatic algorithms discriminating spectral data of unknown serum samples of lymphoma from nonlymphoma serum samples, with an average result of sensitivity and specificity of $84 \%$ and $83 \%$, respectively, was developed. ${ }^{81}$ The same approach was followed in a previous investigation, which relied on the comparison of peak amplitude to the spectra of healthy and lymphoma-affected dogs to identify protein peaks associated with B-cell lymphoma. ${ }^{82}$

A protocol combining MS identification following 2-DGE of serum proteins in dog was recently developed. ${ }^{21}$ The technique was then applied to identify alterations in serum proteome of dogs with multicentric lymphoma. ${ }^{83}$ Proteins were identified by means of MS, after previous PAGE gel separation. The technique detected 31 individual proteins, 10 of which were not previously identified in the serum of healthy animals, including $\alpha 2$ Heremans-Schmid (HS) glycoprotein, haptoglobin, clusterin, $\alpha 2$ macroglobulin, apolipoprotein A1 precursor, apolipoprotein E, $\alpha$-antichymotrypsin, lipopolysaccharide binding protein, antithrombin III, and inter- $\alpha$-trypsin inhibitor whereas one protein, HMWK, was absent from the sera of all the three dogs with lymphoma, as compared to the healthy dogs.

Proteomics also encompass methods that identify posttranslational modification, such as glycosylation and phosphorylation. Glycoproteomic techniques provide biomarkers in oncology ${ }^{84}$ and lectin arrays have been recently developed to determine a glycomic profiling of cancer. ${ }^{85}$ Only one glycoproteomic study has been carried out in dogs, targeting glycosylation differences in diffuse large B-cell lymphoma, and changes in fucosylated peptides were quantified by Global Internal Standard Technology (GIST) stable isotope peptide labelling. ${ }^{86}$ Briefly, tryptic peptides were generated from serum samples of healthy and lymphoma-affected dogs. ${ }^{87}$ Primary amines on peptides were then acylated with GIST isotope labelling reagents, and fucosylated peptides sorted by lectin binding affinity chromatography. After deglycosylation and fractionation, peptides were analysed and quantified with MALDI-TOF. Pre-chemotherapy and post-chemotherapy glycoproteome profiles were also determined. Changes in fucosylation were found in more than $78.9 \%$ peptides from the lymphoma serum samples as compared to those from healthy dogs. A percentage of $61.15 \%$ decreased with remission, and $73 \%$ increased again during relapse of the disease. In addition, individual peptides were compared, and 46 of them, which were found to be similar across the treatment groups, increased their concentration during lymphoma, and then decreased after chemotherapy, to increase again during relapse. Although the scope of the study was narrow (only three animals with 
lymphoma), the results demonstrated the potential of glycopeptide profiling biomarkers for the diagnosis and prognosis of blood malignancies.

\section{Mast cell tumours}

The most frequent skin neoplasm of dogs is cutaneous mast cell tumour (MCT), accounting for $7 \%$ to $21 \%$ of all canine skin tumours. ${ }^{88}$ Several mutations of the KIT gene have been identified, ${ }^{89,90}$ although only $9 \%$ to $17 \%$ of all MCTs actually contain mutations at KIT. ${ }^{91,92}$ Given this background, MCT cells were treated with the tyrosine kinase inhibitor masitinib, aiming to identify changes in both transcriptome and proteome. ${ }^{93}$ Microarray-based transcriptome compared treated with untreated cells along a time course. Changes in transcriptome showed that most nuclear factors were downregulated after treatment with masitinib, as well as genes associated with energy pathways and stress. Masitinib also induced a downregulation of genes regulated by p53, and an upregulation of genes associated with signal transduction, namely T-cell receptor, insulin receptor, and steroid hormone receptors. The changes in gene regulations were time dependent: the number of dysregulated genes increased over the time course. A parallel proteomics analysis was carried out. Most differences were found in cells collected after 72 hours of treatment with masitinib. Remarkably, mRNA expression from six of the eight downregulated proteins was also found to be downregulated. Five of the 15 upregulated proteins were also found to be upregulated at the gene expression level, whereas another four were downregulated. Besides providing a wide source of potential biomarkers to study the effect of masitinib treatment, this study also highlighted the pathways that the neoplastic cells are able to activate (or differentially regulate) to replace KIT activity when its signalling pathway is blocked.

2D-DIGE separation followed by identification by MALDITOF identified differences between low-grade MCT, with a good prognosis, and high-grade MCT, with a poor prognosis. ${ }^{90}$ Proteins associated with cellular stress response, such as HSPA9, PDIA3, TCP1A and TCP1E, were upregulated in highgrade MCT. Other proteins related to cell motility and metastases, including WDR1, ANXA2, ANXA6 ACTB, and ACTR3, were upregulated in high-grade MCT. One protein, TPSAB1, was found to be downregulated in high-grade MCT, as well as transferrin, the last one being downregulated also at gene level. Albumin and ATIC were also differentially regulated (down- and upregulated in MCT, respectively).

\section{Urinary cancers}

Bladder cancer comprises $2 \%$ of naturally occurring cancers in dogs, with transition cell carcinoma (TCC; urothelial carcinoma) being the most common type. ${ }^{94,95}$ Although it is expected that bladder cancer will affect more than $20000 \mathrm{dog}$ per year in the United States alone, ${ }^{95}$ the application of omics techniques to investigate the molecular basis of this type of cancer is still in its infancy. A comparative gene expression analysis has provided molecular support to the possible use of canine invasive urothelial carcinoma as a model for the equivalent human diseases compared with healthy controls and human cancer samples, which in turn were compared to normal bladders. ${ }^{96}$ Luminal and basal tumour subtypes were associated with specific gene expression patterns. Two pathways were found to be particularly enriched, namely EGFR pathway, which was confirmed by means of immunohistochemistry in a further $48 \mathrm{dogs}$, and p53 associated genes.

Differentially expressed proteins were identified by applying 2D-DIGE to samples collected from prostate and bladder carcinoma. ${ }^{97}$ A total of 230 proteins were found to be differentially expressed between neoplastic cancerous and healthy control tissues in prostate carcinoma, and 208 proteins were identified in bladder cancer. Three proteins, namely t keratin 7 , GRP78, and endoplasmin, were found to be significantly overexpressed in carcinomas after comparison with healthy prostate or bladder. A glycoproteomic study on TCC was also carried out. Eighteen distinct fucosylated peptides were similar in dogs with TCC, 12 of which increased more than $50 \%$ in animals with cancer, as compared to healthy controls. ${ }^{87}$

A proteomic characterisation of the canine urinary proteome using LC-MS/MS identified 563 proteins, including 391 proteins belonging to the exosomal fractions, 214 soluble proteins, and 42 proteins that were found in both groups, paving the way for future investigations in urinary cancer biomarkers. ${ }^{20}$ Metabolomic analysis relying on ${ }^{1} \mathrm{H}$ NMR-based metabolite profiling was also carried out on urine of bladder cancer-affected animals. ${ }^{98}$ The study was carried out on cancer-affected dogs, and the results were compared with the urine of healthy animals, allowing to identify six highly sensitive biomarkers, including urea, choline, methylguanosine, citrate, acetone, and $\beta$-hydroxybutyrate.

\section{Osteosarcomas}

Canine osteosarcoma is the most frequent bone primary tumour in the dogs. Canine osteosarcoma exhibits very similar gene expression profiles with human osteosarcoma, ${ }^{40}$ thus providing a very good comparative model, in particular for the paediatric form. ${ }^{99,100}$ Gene expression studies were carried out to classify osteosarcoma affected dogs at diagnosis in "poor" and "good" prognosis, with a survival time of less than or more than 6 months, respectively. ${ }^{101}$ Two groups of animals were identified, namely a short survival group, including dogs with a poor prognosis and a survival rate of less than 6 months, and a long survival group, including dogs with better prognosis, with a survival rate of 6 months or longer. A number of 51 transcripts were found to be differentially expressed and hierarchical clustering, validated by reverse transcriptase polymerase chain reaction (RT-PCR) analysis, revealed that four genes, namely ANKRRD17, MGST1, MRPS31, and NCOR1, were overexpressed in the short survival group. Expression profiling following the same technique identified both biomarkers and pathways associated with the clinical outcome ${ }^{102}$ in dogs that 
responded poorly to chemotherapy and dogs that responded well, as defined by the disease-free intervals $(<100$ days and $>300$ days). Differentially expressed genes related to the hedgehog signalling pathway, such as HHIP, were found to be upregulated in the poor responder cohort.

Gene expression profiles can classify osteosarcoma cell cultures in two molecular groups. ${ }^{103}$ Group 1 featured the over-expression of 125 genes, involved in mitosis, chromosome segregation, and mitotic spindle formation, and a group 2, which overexpressed 157 genes associated to cell migration, adhesion, angiogenesis, proliferation, inflammation, and apoptosis. In vivo gene expression profiling of spontaneous osteosarcoma confirmed differential gene expression signatures. In a pioneer study, the use of gene expression prediction signatures was recently applied aiming to predict chemosensitivity and treatment outcomes in ostosarcoma. ${ }^{104}$ Co-expression extrapolation (COXEN) method ${ }^{105}$ was applied, and canine microarray gene expression data were integrated with human genomic data, and both provided the base of the model to predict response to doxorubicin and carboplatin in canine osteosarcoma, highlighting the potential application of genomic methods to personalised cancer therapy.

\section{Other types of cancer}

Gene profiling studies of other spontaneous tumours have been carried out in dogs, although somehow sporadically. A custom specific cDNA microarray, containing approximately 4000 clones from canine brain cDNA, was used to differentiate primary tumours in the central nervous system. ${ }^{106}$ The result highlighted differences between meningiomas and normal meninges (327 genes), and 564 genes differentiating meningiomas from all other tumours. Microarray analysis was also applied to support the differentiation of soft tissue sarcomas, a category inclusive of tumours with different histological origins, such as fibrosarcomas and peripheral nerve sheath tumours (PNST). Gene expression profiles were then applied to five dog fibrosarcomas and five PNST. ${ }^{107}$ The comparison of the transcriptome revealed that 77 genes were differentially expressed, of which 39 were found to be overexpressed in PNST and 38 were overexpressed in fibrosarcomas. The group of genes upregulated in PNST included genes associated with neuronal differentiation, as well as transcription factors, cytoskeletal proteins, and membrane proteins. The group of genes upregulated in fibrosarcomas coded for src homology 3 domain, or were genes coding for membrane proteins, or protein involved in oxidoreductase processes and transcriptional regulation. The overexpression of the genes with highest expression-namely CLEC3B, GLI1, and DOK4 for PNST, and FHL2, CSK, and PLAGL1 for fibrosarcomas-were validated and confirmed with RT-PCR. Remarkably, the results of this study provided the background for the development of a molecular assay to differentiate the two tumours using a PCR approach with GLI1 and CLEC3B as molecular targets. ${ }^{108}$ The canine is the only species where another relevant tumour, the hemangiosarcoma, develops spontaneously at specific locations such as the heart right auricle and the spleen. Hemangiosarcomas account for up to $7 \%$ of malignant dog tumours. ${ }^{64}$ A gene expression profiling approach demonstrated that hemangiosarcoma is associated with the golden retriever breed, and correlated with the upregulation of VEGFR1. ${ }^{8}$

The pathogenesis of hemangiosarcoma is not entirely clear. In an isolated in vitro system, it was demonstrated that hemangiosarcoma cells can be differentiated from nonmalignant splenic hematoma cells by means of gene expression profiles. ${ }^{109}$ The study identified a transcriptomic signature capable of differentiating hemangiosarcoma cells from nonmalignant endothelial cells of splenic hematoma, and validated two genes, TIMP-1 and $P L Z F$. The identified signatures also allowed differentiation of hemangiosarcomas from other malignancies, including lymphoma, leukaemia, and osteosarcoma. Classification of hemangiosarcomas is also an issue: microarray and RNA-seq were applied to identify molecular and functional subtypes in primary canine hemangiosarcomas. ${ }^{110}$ Three divergent molecular subtypes were identified: group 1 , associated with angiogenesis and endothelia cell function; group 2, associated with inflammation and myeloid differentiation; and group 3, associated with adipogenesis sand lipid transport. Results were confirmed in sphere-cultured cells, demonstrating that enriched progenitor populations also display gene profile resembling that of the three subgroups. A microarray-based transcriptomics has also been applied to determine gene expression profiling of insulinoma, which is the most common malignant pancreatic endocrine cancer in dogs. ${ }^{111-113}$ The aim of the study was to identify (a) the differences in genes that were differentially expressed in primary insulinomas and their metastasis and (b) the differences in genes expressed in two subsets of primary insulinomas. Distinct clusters were identified: high-metastatic groups could be differentiated by the downregulation of PNLIP, $C T R B 1$, and $P A$, as compared to the low-metastatic group. Moreover, a group of 84 genes were found to be downregulated in the metastases, as compared to the primary tumour.

Gene expression profiling was used to study the pathogenesis of histiocytic sarcomas, a rare cancer with high incidence in flatcoated retriever. ${ }^{114}$ Spleen was chosen as the normal equivalent for histiocytoma, and cancers located in defendant districts of the bodies were compared to it by gene expression profiling. A total of 352 genes were found to be differentially expressed when comparing visceral (lung, liver, kidney) histiocytoma with spleen and 319 genes were found to be differentially expressed when comparing undefined locations (knee, shoulder, elbow) with spleen. Nine of the 10 genes analysed were validated with quantitative PCR, confirming that PPBP, SPIC, VCAM1, ENPEP, and ITGAD were downregulated and GTSF1, LUM, Thy1, and Col3a1 were upregulated in both soft tissue and visceral, as compared to normal spleen. Out of the 11 gene that were analysed with RT-PCR, only three, namely C6, CLEC12A, and CCL5, were found to be statistically significantly expressed between visceral and soft tissuelocalised histiocytic sarcomas. ${ }^{115}$

A microarray hybridisation comparative experiment highlighted the impact of epigenetic regulation of miRNA on tumour suppression of human and dog melanoma. ${ }^{116}$ The expression of 
miR-520c-3p was found to be upregulated, and other six microRNAs, namely miR-126, miR-200a, miR-203, miR-205, miR517b, and miR-713, were downregulated. These findings provided the background for the use of miR-203 and miR205 as cell growth inhibitors of canine melanoma.

\section{Unearthing treasures: omics analyses from formalin-fixed, paraffin-embedded tissues}

Fixing pathological specimens with formalin and paraffin embedding (FFPE) is routinely performed as the chosen procedure to preserve tissue morphology. Snap frozen tissue samples still provide the gold standard for omics analyses, but formalinfree fixatives are available as a good alternative (Klopfleisch et al., 2011 ${ }^{118}$ ), enabling parallel histologic and molecular analyses. $^{117}$ Amplification of microRNA, 400-bp-long mRNA, and 1000 -bp-long DNA fragments ${ }^{118}$ was obtained following this technique. Nevertheless, FFPE has been applied for storage of tissues for over a century, and FFPE blocks may be the only available sample type, providing archival specimens that represent an essential source of tissue for retrospective studies. Protocols to extract both protein and nucleic acid material from FFPE tissues have been therefore developed, in order to apply omics to material from archival cases.

Embedding of samples in paraffin after formalin fixation represents a serious challenge for protein extraction. Formaldehyde reacts with primary amines to form Schiff bases, and with amides to form hydroxymethyl compounds. ${ }^{119}$ DNA fragmentation also occurs, caused by low $\mathrm{pH}$ of unbuffered formaldehyde solutions, due to its oxidation to formic acid. ${ }^{120}$ Similar effects have been reported for mRNA, where a complete loss of poly A tails has been also reported. ${ }^{121}$ Consequently, FFPE has negative effects on the recovery and quality of proteins and nucleic acids for omics analyses. ${ }^{122}$ The above effects results in failure of amplifying DNA fragments longer than $200 \mathrm{bp},{ }^{123}$ although amplification of up to $600 \mathrm{bp}$ has been reported, providing high yield of genomic DNA with high quality from FFPE mast cells tumours and cutaneous histiocytomas. ${ }^{124}$

Storage of tissues in FFPE still provide several challenges for RNA extraction. A recent study comparing DNA and RNA isolation from canine oncologic FFPE provides less encouraging results. ${ }^{125}$ RNA integrity number (RIN) was lower than 2.5, and only minor and degraded amounts of RNA were recovered from FFPE tissues, confirming previous studies in human tissues. ${ }^{126}$ Contrary to mRNA extraction, consistent microRNA profiles between frozen and FFPE specimens for the purpose of NGS analyses have been obtained; this good yield may be associated either with the small size of microRNA, or with the way in which these molecules are stored in the cell. ${ }^{127}$ In veterinary medicine, microRNAs have been extracted and quantified by RT-PCR from FFPE tissue, with an apparent good yield and quality. ${ }^{128}$ A recent protocol demonstrated that using archived clinical samples for exome sequencing and miRNA and mRNA profiling of 12 FFPE tumour tissues is feasible, ${ }^{129}$ identifying p53 and $\mathrm{Rb}$ protein as the most mutated genes.

The impact on proteome stability by preserving samples in RNAlater (Thermo Fisher Scientific, Waltham, MA) prior to formalin fixation and paraffin embedding on human soft tissues, using directly frozen samples as a control, has been recently presented. ${ }^{130}$ In a model of dog liver, a protocol combining full-length protein extraction and GeLC-MS/MS analyses on FFPE tissues was developed. Parallel GeLC-MS/MS analyses on FFPE and snap frozen tissues from canine mammary tumours were then carried out. ${ }^{131}$ Results demonstrated that FFPE samples delivered less data, in particular for what concerns high molecular weight proteins. Nonetheless, proteomics results from frozen samples largely converge toward those from FFPE, confirming the informational power of proteomics techniques applied to retrospective cancer research utilising FFPE extracts.

Laser capture microdissection (LCM) provides a valuable tool for the enrichment of a specific cell type within complex tissue samples, and downstream techniques for omics analyses have been developed. ${ }^{132}$ In humans, LC-MS workflows have been developed to obtain laser-captured microdissected pathologic tissues in several diseases, such as colon adenocarcinoma, ${ }^{133}$ breast cancer, ${ }^{134}$ and heart infarction. ${ }^{135}$ Intact proteins, such as prostate-specific antigen (PSA), have been identified by these techniques, ${ }^{136}$ as well as proteins obtained from sclerotic lesions (human glomerular disease), ${ }^{137}$ amyloid, or other conformation involving a loss of solubility of proteins and peptides. ${ }^{138}$ To the best knowledge of the authors, the pairing of laser dissection to proteomics has not been applied to veterinary medicine. Reasons are likely economic, but we believe that due to the decreasing cost of this technology, the application of this technique to veterinary diagnostics in the near future is highly probable.

\section{Conclusions and future perspectives}

This paper reviewed the state of knowledge on the application of omics technologies to canine cancer studies. The number of transcriptomic and proteomics studies carried out in dog pales if compared to those carried out in humans and only a few types of dog cancers have been characterised so far by means of omics techniques. Therefore, several issues remain to be addressed, and most of the molecular pathways and complex gene expression patterns driving cancer in dogs remain undisclosed. In human medicine, clinical sequencing of tumours might soon become routine in oncology. Technology moves rapidly forward and the costs for omics application is constantly dropping. The goal of a $\$ 1000$ genome $^{139}$ has been almost reached, and it is expected that further drops in omics experiment costs will result in an exponential increase of transcriptomics and proteomic studies, which will likely be extended to other omics disciplines such as glycomics and metabolomics in veterinary medicine. Although the perspective of the evaluation of the single patient in veterinary oncology routine practice might appear somehow futuristic in veterinary 
medicine, recent studies have introduced the concept of personalised medicine in veterinary therapy as well. ${ }^{10,67,104,140}$ Therefore, the application of omics and system biology disciplines in veterinary routine practices does not seem that far anymore.

\section{List of abbreviations}

$\begin{array}{ll}\text { 2D/MS } & \begin{array}{l}\text { 2D gel electrophoresis/mass spectrometry } \\ \text { 2-DIGE/MS }\end{array} \\ \text { 2D/MALDI-TOF } & \begin{array}{l}\text { esis/mass spectrometry } \\ \text { 2D gel electrophoresis/matrix-assisted laser } \\ \text { desorption ionisation-time of flight }\end{array} \\ \text { 2-DIGE } & \text { 2-D fluorescence difference gel electrophoresis } \\ \text { 2-DGE } & \begin{array}{l}\text { 2-Dimensional gel electrophoresis } \\ \text { LC-MS/MS }\end{array} \\ \text { MALDI-TOF } & \begin{array}{l}\text { Liquid chromatography-mass spectrometry } \\ \text { time of flight }\end{array} \\ \text { NGS } & \text { Next generation sequencing }\end{array}$

\section{References}

1 B. W. Davis and E. A. Ostrander, ILAR J., 2014, 55, 59-68.

2 C. E. Alvarez, ILAR J., 2014, 55, 16-45.

3 C. Khanna, K. Lindblad-Toh, D. Vail, C. London, P. Bergman, L. Barber, M. Breen, B. Kitchell, E. McNeil, J. F. Modiano, S. Niemi, K. E. Comstock, E. Ostrander, S. Westmoreland and S. Withrow, Nat. Biotechnol., 2006, 24, 1065-1066.

4 J. L. Rowell, D. O. McCarthy and C. E. Alvarez, Trends Mol. Med., 2011, 17, 380-388.

5 C. Khanna, C. London, D. Vail, C. Mazcko and S. Hirschfeld, Clin. Cancer Res., 2009, 15, 5671-5677.

6 M. Paoloni and C. Khanna, Nat. Rev. Cancer, 2008, 8, 147-156.

7 A. L. Shearin and E. A. Ostrander, Dis. Models \& Mech., 2010, 3, 27-34.

8 B. A. Tamburini, S. Trapp, T. L. Phang, J. T. Schappa, L. E. Hunter and J. F. Modiano, PLoS One, 2009, 4, e5549.

9 J. F. Modiano, M. Breen, R. C. Burnett, H. G. Parker, S. Inusah, R. Thomas, P. R. Avery, K. Lindblad-Toh, E. A. Ostrander, G. C. Cutter and A. C. Avery, Cancer Res., 2005, 65, 5654-5661.

10 R. Klopfleisch, Vet. J., 2015, 205, 128-135.

11 J. S. Morris, Vet. J., 2016, DOI: 10.1016/j.tvjl.2016.01.003.

12 A. M. Almeida, A. Bassols, E. Bendixen, M. Bhide, F. Ceciliani, S. Cristobal, P. D. Eckersall, K. Hollung, F. Lisacek, G. Mazzucchelli, M. McLaughlin, I. Miller, J. E. Nally, J. Plowman, J. Renaut, P. Rodrigues, P. Roncada, J. Staric and R. Turk, Animal, 2015, 9, 1-17.

13 F. Ceciliani, D. Eckersall, R. Burchmore and C. Lecchi, Vet. Pathol., 2014, 51, 351-362.

14 K. Lindblad-Toh, C. M. Wade, T. S. Mikkelsen, E. K. Karlsson, D. B. Jaffe, M. Kamal, M. Clamp, J. L. Chang, E. J. Kulbokas, 3rd, M. C. Zody, E. Mauceli, X. Xie, M. Breen, R. K. Wayne, E. A. Ostrander,
C. P. Ponting, F. Galibert, D. R. Smith, P. J. DeJong, E. Kirkness, P. Alvarez, T. Biagi, W. Brockman, J. Butler, C. W. Chin, A. Cook, J. Cuff, M. J. Daly, D. DeCaprio, S. Gnerre, M. Grabherr, M. Kellis, M. Kleber, C. Bardeleben, L. Goodstadt, A. Heger, C. Hitte, L. Kim, K. P. Koepfli, H. G. Parker, J. P. Pollinger, S. M. Searle, N. B. Sutter, R. Thomas, C. Webber, J. Baldwin, A. Abebe, A. Abouelleil, L. Aftuck, M. Ait-Zahra, T. Aldredge, N. Allen, P. An, S. Anderson, C. Antoine, H. Arachchi, A. Aslam, L. Ayotte, P. Bachantsang, A. Barry, T. Bayul, M. Benamara, A. Berlin, D. Bessette, B. Blitshteyn, T. Bloom, J. Blye, L. Boguslavskiy, C. Bonnet, B. Boukhgalter, A. Brown, P. Cahill, N. Calixte, J. Camarata, Y. Cheshatsang, J. Chu, M. Citroen, A. Collymore, P. Cooke, T. Dawoe, R. Daza, K. Decktor, S. DeGray, N. Dhargay, K. Dooley, K. Dooley, P. Dorje, K. Dorjee, L. Dorris, N. Duffey, A. Dupes, O. Egbiremolen, R. Elong, J. Falk, A. Farina, S. Faro, D. Ferguson, P. Ferreira, S. Fisher, M. FitzGerald, K. Foley, C. Foley, A. Franke, D. Friedrich, D. Gage, M. Garber, G. Gearin, G. Giannoukos, T. Goode, A. Goyette, J. Graham, E. Grandbois, K. Gyaltsen, N. Hafez, D. Hagopian, B. Hagos, J. Hall, C. Healy, R. Hegarty, T. Honan, A. Horn, N. Houde, L. Hughes, L. Hunnicutt, M. Husby, B. Jester, C. Jones, A. Kamat, B. Kanga, C. Kells, D. Khazanovich, A. C. Kieu, P. Kisner, M. Kumar, K. Lance, T. Landers, M. Lara, W. Lee, J. P. Leger, N. Lennon, L. Leuper, S. LeVine, J. Liu, X. Liu, Y. Lokyitsang, T. Lokyitsang, A. Lui, J. Macdonald, J. Major, R. Marabella, K. Maru, C. Matthews, S. McDonough, T. Mehta, J. Meldrim, A. Melnikov, L. Meneus, A. Mihalev, T. Mihova, K. Miller, R. Mittelman, V. Mlenga, L. Mulrain, G. Munson, A. Navidi, J. Naylor, T. Nguyen, N. Nguyen, C. Nguyen, T. Nguyen, R. Nicol, N. Norbu, C. Norbu, N. Novod, T. Nyima, P. Olandt, B. O'Neill, K. O'Neill, S. Osman, L. Oyono, C. Patti, D. Perrin, P. Phunkhang, F. Pierre, M. Priest, A. Rachupka, S. Raghuraman, R. Rameau, V. Ray, C. Raymond, F. Rege, C. Rise, J. Rogers, P. Rogov, J. Sahalie, S. Settipalli, T. Sharpe, T. Shea, M. Sheehan, N. Sherpa, J. Shi, D. Shih, J. Sloan, C. Smith, T. Sparrow, J. Stalker, N. Stange-Thomann, S. Stavropoulos, C. Stone, S. Stone, S. Sykes, P. Tchuinga, P. Tenzing, S. Tesfaye, D. Thoulutsang, Y. Thoulutsang, K. Topham, I. Topping, T. Tsamla, H. Vassiliev, V. Venkataraman, A. Vo, T. Wangchuk, T. Wangdi, M. Weiand, J. Wilkinson, A. Wilson, S. Yadav, S. Yang, X. Yang, G. Young, Q. Yu, J. Zainoun, L. Zembek, A. Zimmer and E. S. Lander, Nature, 2005, 438, 803-819.

15 M. P. Hoeppner, A. Lundquist, M. Pirun, J. R. Meadows, N. Zamani, J. Johnson, G. Sundstrom, A. Cook, M. G. FitzGerald, R. Swofford, E. Mauceli, B. T. Moghadam, A. Greka, J. Alfoldi, A. Abouelleil, L. Aftuck, D. Bessette, A. Berlin, A. Brown, G. Gearin, A. Lui, J. P. Macdonald, M. Priest, T. Shea, J. Turner-Maier, A. Zimmer, E. S. Lander, F. di Palma, K. Lindblad-Toh and M. G. Grabherr, PLoS One, 2014, 9, e91172. 
16 A. Duleba, K. Skonieczna, W. Bogdanowicz, B. Malyarchuk and T. Grzybowski, Forensic Sci. Int.: Genet., 2015, 19, 123-129.

17 B. Bai, W. M. Zhao, B. X. Tang, Y. Q. Wang, L. Wang, Z. Zhang, H. C. Yang, Y. H. Liu, J. W. Zhu, D. M. Irwin, G. D. Wang and Y. P. Zhang, Nucleic Acids Res., 2015, 43, D777-D783.

18 M. Fernandes, N. Rosa, E. Esteves, M. J. Correia, J. Arrais, P. Ribeiro, H. Vala and M. Barros, J. Proteomics, 2016, 136, 193-201.

19 S. Wagner, S. Willenbrock, I. Nolte and H. Murua Escobar, Front. Genet., 2013, 4, 46.

20 L. E. Brandt, E. J. Ehrhart, H. Scherman, C. S. Olver, A. A. Bohn and J. E. Prenni, Vet. Clin. Pathol., 2014, 43, 193-205.

21 M. J. Atherton, M. Braceland, S. Fontaine, M. M. Waterston, R. J. Burchmore, S. Eadie, P. D. Eckersall and J. S. Morris, Vet. J., 2013, 196, 320-324.

22 L. I. Lilja-Maula, M. J. Palviainen, H. P. Heikkila, M. R. Raekallio and M. M. Rajamaki, Am. J. Vet. Res., 2013, 74, 148-154.

23 K. Nakamura, T. Miyasho, S. Nomura, H. Yokota and T. Nakade, J. Vet. Med. Sci., 2012, 74, 751-756.

24 M. Zamani-Ahmadmahmudi, S. M. Nassiri, I. Jahanzad, D. Shirani, R. Rahbarghazi and B. Yazdani, Tissue Cell, 2013, 45, 183-190.

25 M. Winiarczyk, D. Winiarczyk, T. Banach, L. Adaszek, J. Madany, J. Mackiewicz, D. Pietras-Ozga and S. Winiarczyk, PLoS One, 2015, 10(12), e0144242.

26 C. de Freitas Campos, N. Cole, D. Van Dyk, B. J. Walsh, P. Diakos, D. Almeida, A. Torrecilhas, J. L. Laus and M. D. Willcox, Res. Vet. Sci., 2008, 85, 349-352.

27 I. Miller, A. Presslmayer-Hartler, R. Wait, K. Hummel, C. Sensi, I. Eberini, E. Razzazi-Fazeli and E. Gianazza, J. Proteomics, 2014, 106, 30-45.

28 F. Liu, T. K. Jenssen, J. Trimarchi, C. Punzo, C. L. Cepko, L. Ohno-Machado, E. Hovig and W. P. Kuo, BMC Genomics, 2007, 8, 153.

29 J. H. Malone and B. Oliver, BMC Biol., 2011, 9, 34.

30 R. Klopfleisch and A. D. Gruber, Sci. World J., 2012, 2012, 254962.

31 K. U. Sorenmo, F. S. Shofer and M. H. Goldschmidt, J. Vet. Intern. Med., 2000, 14, 266-270.

32 R. Klopfleisch, H. von Euler, G. Sarli, S. S. Pinho, F. Gartner and A. D. Gruber, Vet. Pathol., 2011, 48, 98-116.

33 M. A. Rodrigues, C. O. Gamba, J. A. Faria, E. Ferreira, A. M. Goes, D. A. Gomes and G. D. Cassali, Pathol., Res. Pract., 2015, 212, 340-344.

34 K. A. Schafer, G. Kelly, R. Schrader, W. C. Griffith, B. A. Muggenburg, L. A. Tierney, J. F. Lechner, E. B. Janovitz and F. F. Hahn, Vet. Pathol., 1998, 35, 168-177.

35 J. K. Simmons, B. E. Hildreth, 3rd, W. Supsavhad, S. M. Elshafae, B. B. Hassan, W. P. Dirksen, R. E. Toribio and T. J. Rosol, Vet. Pathol., 2015, 52, 827-841.

36 R. Shafiee, J. Javanbakht, N. Atyabi, P. Kheradmand, D. Kheradmand, A. Bahrami, H. Daraei and F. Khadivar, Cancer Cell Int., 2013, 13, 79.
37 A. J. Matos and A. A. Santos, Vet. J., 2015, 205, 136-143. 38 A. A. Santos and A. J. Matos, Vet. J., 2015, 205, 144-153.

39 H. Liu, T. L. McDowell, N. E. Hanson, X. Tang, J. Fujimoto and J. Rodriguez-Canales, Vet. Pathol., 2014, 51, 257-269.

40 K. M. Pawlowski, M. Krol, A. Majewska, A. BadowskaKozakiewicz, J. A. Mol, E. Malicka and T. Motyl, J. Physiol. Pharmacol., 2009, 60(1), 85-94.

41 M. Krol, K. M. Pawlowski, J. Skierski, P. Turowski, A. Majewska, J. Polanska, M. Ugorski, R. E. Morty and T. Motyl, J. Appl. Genet., 2010, 51, 169-183.

42 N. A. Rao, M. E. van Wolferen, A. Gracanin, S. F. Bhatti, M. Krol, F. C. Holstege and J. A. Mol, J. Physiol. Pharmacol., 2009, 60(1), 73-84.

43 M. Krol, J. Mucha, K. Majchrzak, A. Homa, M. Bulkowska, A. Majewska, M. Gajewska, M. Pietrzak, M. Perszko, K. Romanowska, K. Pawlowski, E. Manuali, E. Hellmen and T. Motyl, PLoS One, 2014, 9, e83995.

44 M. Krol, K. M. Pawlowski, K. Majchrzak, M. Gajewska, A. Majewska and T. Motyl, BMC Vet. Res., 2012, 8, 16.

45 A. Rybicka, J. Mucha, K. Majchrzak, B. Taciak, E. Hellmen, T. Motyl and M. Krol, J. Physiol. Pharmacol., 2015, 66, 29-37.

46 K. De Leeneer and K. Claes, Adv. Exp. Med. Biol., 2015, 867, 263-275.

47 J. L. Munoz-Rodriguez, L. Vrba, B. W. Futscher, C. Hu, I. K. Komenaka, M. M. Meza-Montenegro, L. E. GutierrezMillan, A. Daneri-Navarro, P. A. Thompson and M. E. Martinez, PLoS One, 2015, 10, e0124340.

48 Y. Han, Y. Zhang, T. Jia and Y. Sun, Tumor Biol., 2015, 36, 1385-1394.

49 M. Krol, K. M. Pawlowski, K. Szyszko, H. Maciejewski, I. Dolka, E. Manuali, M. Jank and T. Motyl, BMC Vet. Res., 2012, 8, 35.

50 P. R. Jungblut, Microbes Infect., 2001, 3, 831-840.

51 P. R. Jungblut, G. Grabher and G. Stoffler, Electrophoresis, 1999, 20, 3611-3622.

52 M. Zamani-Ahmadmahmudi, S. M. Nassiri and R. Rahbarghazi, Electrophoresis, 2014, 35, 901-910.

53 R. Klopfleisch, D. Lenze, M. Hummel and A. D. Gruber, Vet. J., 2011, 190, 236-243.

54 M. Krol, J. Polanska, K. M. Pawlowski, P. Turowski, J. Skierski, A. Majewska, M. Ugorski, R. E. Morty and T. Motyl, J. Appl. Genet., 2010, 51, 37-50.

55 R. Klopfleisch, D. Lenze, M. Hummel and A. D. Gruber, BMC Cancer, 2010, 10, 618.

56 J. Mucha, K. Majchrzak, B. Taciak, E. Hellmen and M. Krol, PLoS One, 2014, 9, e103249.

57 R. Klopfleisch, P. Klose, C. Weise, A. Bondzio, G. Multhaup, R. Einspanier and A. D. Gruber, J. Proteome Res., 2010, 9, 6380-6391.

58 P. Klose, C. Weise, A. Bondzio, G. Multhaup, R. Einspanier, A. D. Gruber and R. Klopfleisch, J. Proteome Res., 2011, 10, 4405-4415.

59 H. Wensman, H. Goransson, K. J. Leuchowius, S. Stromberg, F. Ponten, A. Isaksson, G. R. Rutteman, N. E. Heldin, G. Pejler and E. Hellmen, Breast Cancer Res. Treat., 2009, 118, 333-343. 
60 H. Wensman, N. E. Heldin, G. Pejler and E. Hellmen, PLoS One, 2009, 4, e7133.

61 A. da Costa, D. Lenze, M. Hummel, B. Kohn, A. D. Gruber and R. Klopfleisch, J. Comp. Pathol., 2012, 146, 143-151.

62 K. A. Hahn, L. Bravo, W. H. Adams and D. L. Frazier, In Vivo, 1994, 8, 133-143.

63 K. Hansen and C. Khanna, Eur. J. Cancer, 2004, 40, 858-880.

64 D. M. Vail and E. G. MacEwen, Cancer Invest., 2000, 18, 781-792.

65 D. Ito, A. M. Frantz and J. F. Modiano, Vet. Immunol. Immunopathol., 2014, 159, 192-201.

66 K. L. Richards and S. E. Suter, Immunol. Rev., 2015, 263, 173-191.

67 K. L. Richards, A. A. Motsinger-Reif, H. W. Chen, Y. Fedoriw, C. Fan, D. M. Nielsen, G. W. Small, R. Thomas, C. Smith, S. S. Dave, C. M. Perou, M. Breen, L. B. Borst and S. E. Suter, Cancer Res., 2013, 73, 5029-5039.

68 M. P. Starkey and S. Murphy, Vet. Comp. Oncol., 2010, 8, 56-71.

69 M. Mooney, J. Bond, N. Monks, E. Eugster, D. Cherba, P. Berlinski, S. Kamerling, K. Marotti, H. Simpson, T. Rusk, W. Tembe, C. Legendre, H. Benson, W. Liang and C. P. Webb, PLoS One, 2013, 8, e61088.

70 M. A. Mudaliar, R. D. Haggart, G. Miele, G. Sellar, K. A. Tan, J. R. Goodlad, E. Milne, D. M. Vail, I. Kurzman, D. Crowther and D. J. Argyle, PLoS One, 2013, 8, e72591.

71 I. Elvers, J. Turner-Maier, R. Swofford, M. Koltookian, J. Johnson, C. Stewart, C. Z. Zhang, S. E. Schumacher, R. Beroukhim, M. Rosenberg, R. Thomas, E. Mauceli, G. Getz, F. D. Palma, J. F. Modiano, M. Breen, K. Lindblad-Toh and J. Alfoldi, Genome Res., 2015, 25, 1634-1645.

72 A. M. Frantz, A. L. Sarver, D. Ito, T. L. Phang, A. KarimpourFard, M. C. Scott, V. E. Valli, K. Lindblad-Toh, K. E. Burgess, B. D. Husbands, M. S. Henson, A. Borgatti, W. C. Kisseberth, L. E. Hunter, M. Breen, T. D. O'Brien and J. F. Modiano, Vet. Pathol., 2013, 50, 693-703.

73 V. E. Valli, M. San Myint, A. Barthel, D. Bienzle, J. Caswell, F. Colbatzky, A. Durham, E. J. Ehrhart, Y. Johnson, C. Jones, M. Kiupel, P. Labelle, S. Lester, M. Miller, P. Moore, S. Moroff, P. Roccabianca, J. Ramos-Vara, A. Ross, T. Scase, H. Tvedten and W. Vernau, Vet. Pathol., 2011, 48, 198-211.

74 D. L. McCaw, A. S. Chan, A. L. Stegner, B. Mooney, J. N. Bryan, S. E. Turnquist, C. J. Henry, H. Alexander and S. Alexander, Clin. Cancer Res., 2007, 13, 2496-2503.

75 S. Bracha, M. McNamara, I. Hilgart, M. Milovancev, J. Medlock, C. Goodall, S. Wickramasekara and C. S. Maier, Anal. Biochem., 2014, 455, 41-47.

76 J. Glaser, M. H. Neumann, Q. Mei, B. Betz, N. Seier, I. Beyer, T. Fehm, H. Neubauer, D. Niederacher and M. C. Fleisch, BioMed Res. Int., 2014, 2014, 379847.

77 K. Kimura, H. Ojima, D. Kubota, M. Sakumoto, Y. Nakamura, T. Tomonaga, T. Kosuge and T. Kondo, J. Proteomics, 2013, 78, 362-373.
78 S. H. Liao, X. Y. Zhao, Y. H. Han, J. Zhang, L. S. Wang, L. Xia, K. W. Zhao, Y. Zheng, M. Guo and G. Q. Chen, Proteomics, 2009, 9, 3901-3912.

79 S. N. Voisin, O. Krakovska, A. Matta, L. V. DeSouza, A. D. Romaschin, T. J. Colgan and K. W. Siu, PLoS One, 2011, 6, e16352.

80 J. A. Westbrook, D. A. Cairns, J. Peng, V. Speirs, A. M. Hanby, I. Holen, S. L. Wood, P. D. Ottewell, H. Marshall, R. E. Banks, P. J. Selby, R. E. Coleman and J. E. Brown, J. Natl. Cancer Inst., 2016, 108, djv360, DOI: 10.1093/jnci/djv360.

81 L. Ratcliffe, S. Mian, K. Slater, H. King, M. Napolitano, D. Aucoin and A. Mobasheri, Vet. Comp. Oncol., 2009, 7, 92-105.

82 P. J. Gaines, T. D. Powell, S. J. Walmsley, K. L. Estredge, N. Wisnewski, D. T. Stinchcomb, S. J. Withrow and S. E. Lana, Am. J. Vet. Res., 2007, 68, 405-410.

83 M. J. Atherton, M. Braceland, J. Harvie, R. J. Burchmore, S. Eadie, P. D. Eckersall and J. S. Morris, Vet. J., 2013, 196, 315-319.

84 E. H. Kim and D. E. Misek, Int. J. Proteomics, 2011, 2011, 601937.

85 P. Syed, K. Gidwani, H. Kekki, J. Leivo, K. Pettersson and U. Lamminmaki, Proteomics, 2016, 16, 1257-1265.

86 L. Xiong, D. Andrews and F. Regnier, J. Proteome Res., 2003, 2, 618-625.

87 C. R. Wilson, F. E. Regnier, D. W. Knapp, R. E. Raskin, D. A. Andrews and S. B. Hooser, Vet. Comp. Oncol., 2008, 6, 171-181.

88 M. M. Welle, C. R. Bley, J. Howard and S. Rufenacht, Veterinary Dermatology, 2008, 19, 321-339.

89 S. Downing, M. B. Chien, P. H. Kass, P. E. Moore and C. A. London, Am. J. Vet. Res., 2002, 63, 1718-1723.

90 P. Schlieben, A. Meyer, C. Weise, A. Bondzio, R. Einspanier, A. D. Gruber and R. Klopfleisch, Vet. J., 2012, 194, 210-214.

91 S. Letard, Y. Yang, K. Hanssens, F. Palmerini, P. S. Leventhal, S. Guery, A. Moussy, J. P. Kinet, O. Hermine and P. Dubreuil, Mol. Cancer Res., 2008, 6, 1137-1145.

92 J. D. Webster, V. Yuzbasiyan-Gurkan, R. A. Miller, J. B. Kaneene and M. Kiupel, Vet. Pathol., 2007, 44, 298-308.

93 R. Klopfleisch, A. Meyer, P. Schlieben, A. Bondzio, C. Weise, D. Lenze, M. Hummel, R. Einspanier and A. D. Gruber, BMC Vet. Res., 2012, 8, 96.

94 C. M. Fulkerson and D. W. Knapp, Vet. J., 2015, 205, 217-225.

95 D. W. Knapp, J. A. Ramos-Vara, G. E. Moore, D. Dhawan, P. L. Bonney and K. E. Young, ILAR J., 2014, 55, 100-118.

96 D. Dhawan, M. Paoloni, S. Shukradas, D. R. Choudhury, B. A. Craig, J. A. Ramos-Vara, N. Hahn, P. L. Bonney, C. Khanna and D. W. Knapp, PLoS One, 2015, 10, e0136688.

97 B. LeRoy, A. Painter, H. Sheppard, L. Popiolek, M. SamuelFoo and T. M. Andacht, Vet. Comp. Oncol., 2007, 5, 119-130. 
98 J. Zhang, S. Wei, L. Liu, G. A. N. Gowda, P. Bonney, J. Stewart, D. W. Knapp and D. Raftery, Biochim. Biophys. Acta, Mol. Basis Dis., 2012, 1822, 1807-1814.

99 J. M. Fenger, C. A. London and W. C. Kisseberth, ILAR J., 2014, 55, 69-85.

100 K. S. Rankin, M. Starkey, J. Lunec, C. H. Gerrand, S. Murphy and S. Biswas, Pediatr. Blood Cancer, 2012, 58, 327-333.

101 G. T. Selvarajah, J. Kirpensteijn, M. E. van Wolferen, N. A. Rao, H. Fieten and J. A. Mol, Mol. Cancer, 2009, 8, 72 .

102 L. E. O'Donoghue, A. A. Ptitsyn, D. A. Kamstock, J. Siebert, R. S. Thomas and D. L. Duval, BMC Cancer, 2010, 10, 506.

103 M. C. Scott, A. L. Sarver, K. J. Gavin, V. Thayanithy, D. M. Getzy, R. A. Newman, G. R. Cutter, K. LindbladToh, W. C. Kisseberth, L. E. Hunter, S. Subramanian, M. Breen and J. F. Modiano, Bone, 2011, 49, 356-367.

104 J. S. Fowles, K. C. Brown, A. M. Hess, D. L. Duval and D. L. Gustafson, BMC Bioinf., 2016, 17, 93.

105 J. K. Lee, D. M. Havaleshko, H. Cho, J. N. Weinstein, E. P. Kaldjian, J. Karpovich, A. Grimshaw and D. Theodorescu, Proc. Natl. Acad. Sci. U. S. A., 2007, 104, 13086-13091.

106 S. A. Thomson, E. Kennerly, N. Olby, J. R. Mickelson, D. E. Hoffmann, P. J. Dickinson, G. Gibson and M. Breen, Vet. Pathol., 2005, 42, 550-558.

107 R. Klopfleisch, A. Meyer, D. Lenze, M. Hummel and A. D. Gruber, J. Comp. Pathol., 2013, 148, 197-205.

108 A. Meyer and R. Klopfleisch, J. Comp. Pathol., 2014, 150, 198-203.

109 B. A. Tamburini, T. L. Phang, S. P. Fosmire, M. C. Scott, S. C. Trapp, M. M. Duckett, S. R. Robinson, J. E. Slansky, L. C. Sharkey, G. R. Cutter, J. W. Wojcieszyn, D. Bellgrau, R. M. Gemmill, L. E. Hunter and J. F. Modiano, BMC Cancer, 2010, 10, 619.

110 B. H. Gorden, J. H. Kim, A. L. Sarver, A. M. Frantz, M. Breen, K. Lindblad-Toh, T. D. O’Brien, L. C. Sharkey, J. F. Modiano and E. B. Dickerson, Am. J. Pathol., 2014, 184, 985-995.

111 F. O. Buishand, J. Kirpensteijn, A. A. Jaarsma, E. J. Speel, M. Kik and J. A. Mol, Vet. J., 2013, 197, 192-197.

112 F. O. Buishand, J. Visser, M. Kik, A. Grone, R. I. Keesler, I. H. Briaire-de Bruijn and J. Kirpensteijn, Vet. J., 2014, 201, $57-63$.

113 C. M. Goutal, B. L. Brugmann and K. A. Ryan, J. Am. Anim. Hosp. Assoc., 2012, 48, 151-163.

114 K. M. Boerkamp, M. van der Kooij, F. G. van Steenbeek, M. E. van Wolferen, M. J. Groot Koerkamp, D. van Leenen, G. C. Grinwis, L. C. Penning, E. A. Wiemer and G. R. Rutteman, PLoS One, 2013, 8, e71094.

115 K. M. Boerkamp, F. G. van Steenbeek, L. C. Penning, M. J. Groot Koerkamp, D. van Leenen, M. Vos-Loohuis, G. C. Grinwis and G. R. Rutteman, PLoS One, 2014, 9, e98258.

116 S. Noguchi, T. Mori, Y. Hoshino, N. Yamada, K. Maruo and Y. Akao, Vet. Comp. Oncol., 2013, 11, 113-123.
117 S. Gundisch, C. Schott, C. Wolff, K. Tran, C. Beese, C. Viertler, K. Zatloukal and K. F. Becker, PLoS One, 2013, 8, e60638.

118 R. Klopfleisch, M. von Deetzen, A. T. Weiss, J. Weigner, F. Weigner, J. Plendl and A. D. Gruber, Vet. Pathol., 2013, 50, 191-199.

119 R. Thavarajah, V. K. Mudimbaimannar, J. Elizabeth, U. K. Rao and K. Ranganathan, JOMFP, 2012, 16, 400-405.

120 S. Bonin, F. Hlubek, J. Benhattar, C. Denkert, M. Dietel, P. L. Fernandez, G. Hofler, H. Kothmaier, B. Kruslin, C. M. Mazzanti, A. Perren, H. Popper, A. Scarpa, P. Soares, G. Stanta and P. J. Groenen, Virchows Arch., 2010, 457, 309-317.

121 M. Srinivasan, D. Sedmak and S. Jewell, Am. J. Pathol., 2002, 161, 1961-1971.

122 R. Klopfleisch, A. T. Weiss and A. D. Gruber, Histol. Histopathol., 2011, 26, 797-810.

123 U. Lehmann and H. Kreipe, Methods, 2001, 25, 409-418.

124 A. T. Weiss, N. M. Delcour, A. Meyer and R. Klopfleisch, Vet. Pathol., 2011, 48, 834-838.

125 A. Granato, M. Giantin, P. Ariani, A. Carminato, C. Baratto, E. Zorzan, M. Vascellari, E. Bozzato, M. Dacasto and F. Mutinelli, J. Vet. Diagn. Invest., 2014, 26, 117-124.

126 N. Ludyga, B. Grunwald, O. Azimzadeh, S. Englert, H. Hofler, S. Tapio and M. Aubele, Virchows Arch., 2012, 460, 131-140.

127 S. Tam, R. de Borja, M. S. Tsao and J. D. McPherson, Lab. Invest., 2014, 94, 350-358.

128 F. Albonico, M. Mortarino, G. Avallone, G. Gioia, S. Comazzi and P. Roccabianca, Vet. Immunol. Immunopathol., 2013, 155, 117-123.

129 F. Vaca-Paniagua, R. M. Alvarez-Gomez, H. A. MaldonadoMartinez, C. Perez-Plasencia, V. Fragoso-Ontiveros, F. LasaGonsebatt, L. A. Herrera, D. Cantu, E. Bargallo-Rocha, A. Mohar, G. Durand, N. Forey, C. Voegele, M. Vallee, F. Le Calvez-Kelm, J. McKay, M. Ardin, S. Villar, J. Zavadil and M. Olivier, PLoS One, 2015, 10, e0126762.

130 T. B. Bennike, K. Kastaniegaard, S. Padurariu, M. Gaihede, S. Birkelund, V. Andersen and A. Stensballe, Data in Brief, 2016, 6, 942-947.

131 A. Tanca, D. Pagnozzi, G. P. Burrai, M. Polinas, S. Uzzau, E. Antuofermo and M. F. Addis, J. Proteomics, 2012, 77, 561-576.

132 D. Liu, H. Xiong, A. E. Ellis, N. C. Northrup, C. O. Rodriguez, Jr., R. M. O'Regan, S. Dalton and S. Zhao, Cancer Res., 2014, 74, 5045-5056.

133 Y. Mu, Y. Chen, G. Zhang, X. Zhan, Y. Li, T. Liu, G. Li, M. Li, Z. Xiao, X. Gong and Z. Chen, Electrophoresis, 2013, 34, 1679-1692.

134 D. Thakur, T. Rejtar, D. Wang, J. Bones, S. Cha, B. Clodfelder-Miller, E. Richardson, S. Binns, S. Dahiya, D. Sgroi and B. L. Karger, J. Chromatogr. A, 2011, 1218, 8168-8174.

135 Y. Kakimoto, S. Ito, H. Abiru, H. Kotani, M. Ozeki, K. Tamaki and T. Tsuruyama, J. Am. Heart Assoc., 2013, 2, e000565. 
136 M. Lorey, B. Adler, H. Yan, R. Soliymani, S. Ekstrom, J. YliKauhaluoma, T. Laurell and M. Baumann, Anal. Chem., 2015, 87, 5255-5262.

137 Y. Zhang, B. Xu, N. Kinoshita, Y. Yoshida, M. Tasaki, H. Fujinaka, S. Magdeldin, E. Yaoita and T. Yamamoto, J. Proteomics, 2015, 123, 89-100.

138 N. S. Nielsen, E. T. Poulsen, G. K. Klintworth and J. J. Enghild, J. Proteomics Bioinf., 2014, 002, DOI: 10.4172/jpb.S8-002.
139 M. F. Addis, A. Tanca, D. Pagnozzi, S. Crobu, G. Fanciulli, P. Cossu-Rocca and S. Uzzau, Proteomics, 2009, 9, 3815-3823.

140 M. Paoloni, C. Webb, C. Mazcko, D. Cherba, W. Hendricks, S. Lana, E. J. Ehrhart, B. Charles, H. Fehling, L. Kumar, D. Vail, M. Henson, M. Childress, B. Kitchell, C. Kingsley, S. Kim, M. Neff, B. Davis, C. Khanna and J. Trent, PLoS One, 2014, 9, e90028. 